
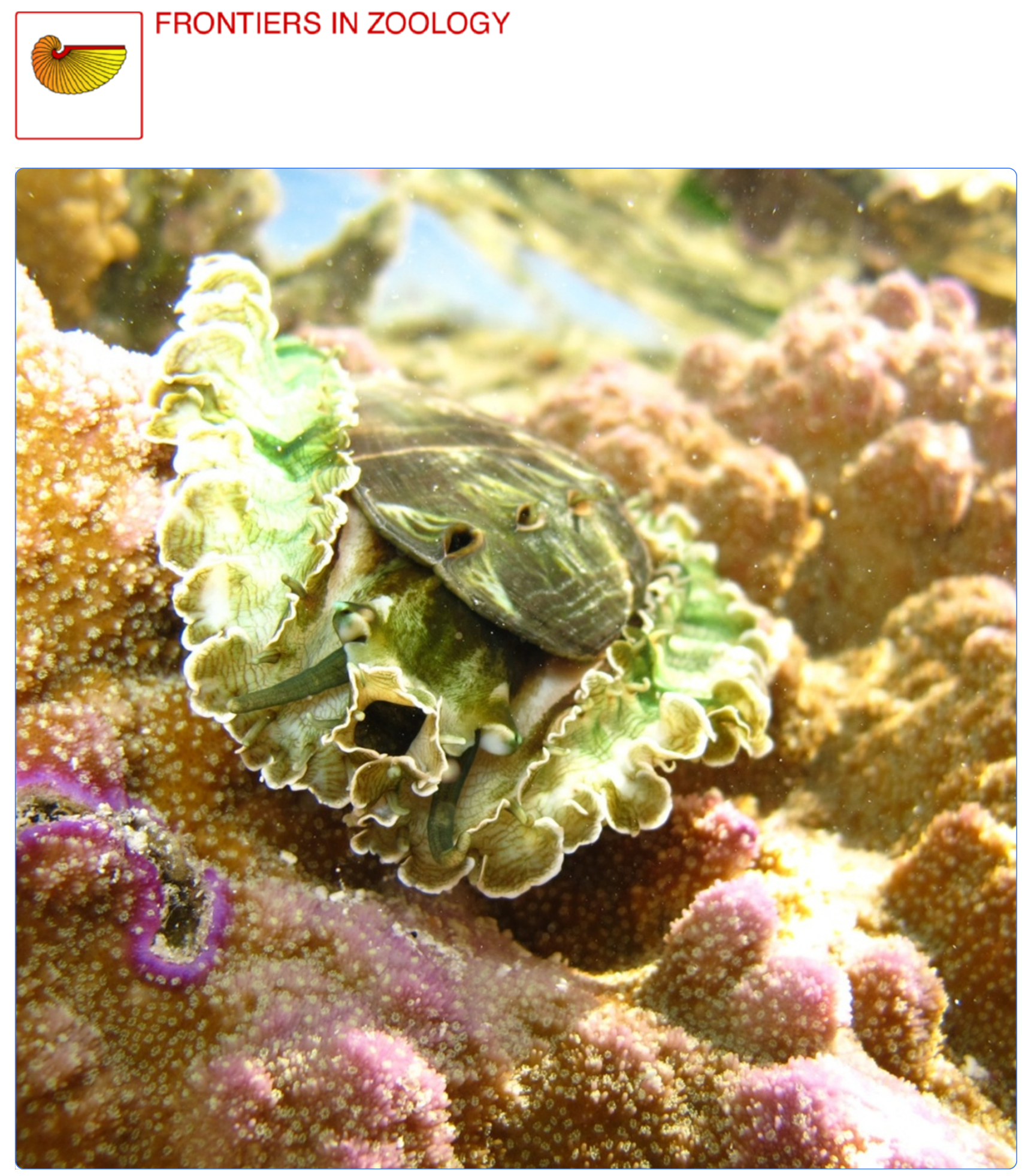

\title{
Marked changes in neuropeptide expression accompany broadcast spawnings in the gastropod Haliotis asinina
}

York et al. 


\title{
Marked changes in neuropeptide expression accompany broadcast spawnings in the gastropod Haliotis asinina
}

Patrick S York', Scott F Cummins ${ }^{1,2}$, Sandie M Degnan ${ }^{1}$, Ben J Woodcroft ${ }^{1,3}$ and Bernard M Degnan ${ }^{1 *}$

\begin{abstract}
Introduction: A huge diversity of marine species reproduce by synchronously spawning their gametes into the water column. Although this species-specific event typically occurs in a particular season, the precise time and day of spawning often can not be predicted. There is little understanding of how the environment (e.g. water temperature, day length, tidal and lunar cycle) regulates a population's reproductive physiology to synchronise a spawning event. The Indo-Pacific tropical abalone, Haliotis asinina, has a highly predictable spawning cycle, where individuals release gametes on the evenings of spring high tides on new and full moons during the warmer half of the year. These calculable spawning events uniquely allow for the analysis of the molecular and cellular processes underlying reproduction. Here we characterise neuropeptides produced in $H$. asinina ganglia that are known in egg-laying molluscs to control vital aspects of reproduction.

Results: We demonstrate that genes encoding APGWamide, myomodulin, the putative proctolin homologue whitnin, FMRFamide, a schistosomin-like peptide (SLP), a molluscan insulin-related peptide (MIP) and a haliotid growthassociated peptide (HGAP) all are differentially expressed in the anterior ganglia during the two week spawning cycle in both male and female abalone. Each gene has a unique and sex-specific expression profile. Despite these differences, expression levels in most of the genes peak at or within $12 \mathrm{~h}$ of the spawning event. In contrast, lowest levels of transcript abundance typically occurs $36 \mathrm{~h}$ before and $24 \mathrm{~h}$ after spawning, with differences in peak and low expression levels being most pronounced in genes orthologous to known molluscan reproduction neuromodulators.

Conclusions: Exploiting the predictable semi-lunar spawning cycle of the gastropod $H$. asinina, we have identified a suite of evolutionarily-conserved, mollusc-specific and rapidly-evolving neuropeptides that appear to contribute to the regulation of spawning. Dramatic increases and decreases in ganglionic neuropeptide expression levels from $36 \mathrm{~h}$ before to $24 \mathrm{~h}$ after the broadcast spawning event are consistent with these peptides having a regulatory role in translating environmental signals experienced by a population into a synchronous physiological output, in this case, the release of gametes.
\end{abstract}

Keywords: Reproduction, Tropical abalone, Haliotis asinina, Neuropeptide, Neuromodulator

\section{Introduction}

The Mollusca is an extraordinarily diverse and successful phylum whose members occupy a wide range of terrestrial, freshwater and marine habitats. In the marine environment, molluscs currently account for approximately $23 \%$ of the 230,000 known animal species, a proportion rivalled only by the Crustacea [1], and it is estimated that

\footnotetext{
*Correspondence: b.degnan@uq.edu.au

${ }^{1}$ Centre for Marine Science, School of Biological Sciences, University of

Queensland, Brisbane, Queensland 4072, Australia

Full list of author information is available at the end of the article
}

over $50 \%$ of extant molluscs still have yet to be discovered and described [2]. The success of marine molluscs can be attributed partially to their varied modes of reproduction, which range from synchronous broadcast spawning entrained by environmental cues (e.g. chitons, bivalves and gastropods) to copulation that is accompanied by species-specific behaviours (cephalopods and gastropods).

Synchronised broadcast spawning of vast numbers of gametes enables extensive mixing of genetically diverse gametes sourced from multiple relatively sedentary individuals. The ensuing pelagic larval phase enables

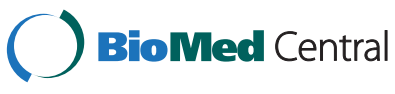

(c) 2012 York et al.; licensee BioMed Central Ltd. This is an Open Access article distributed under the terms of the Creative Commons Attribution License ( $h$ ttp://creativecommons.org/licenses/by/2.0), which permits unrestricted use, distribution, and reproduction in any medium, provided the original work is properly cited. 
widespread dispersal of offspring, potentially increasing rates of survival and allowing gene flow between geographically-distant populations (e.g. [3-5]). Despite the importance of the synchronisation of spawning in molluscs and other marine animals in maximising fertilisation and dispersal, there currently is little understanding of the controlling mechanisms. Although day length, water temperature, lunar cycle and tidal cycle have all been correlated with gamete release (e.g. [6-11]), only in a few cases have the environmental cues that induce spawning been characterised to a level that spawning events can be predicted with high accuracy $[7,12-16]$. The endogenous physiological changes that result in the synchronous release of gametes within a population or species remain largely unknown across the animal kingdom.

In molluscs, regulation of the reproductive cycle has been attributed at least in part to various neuropeptides. Investigations primarily in egg-laying species suggest that regulation is achieved not by any single peptide, but rather by a complex cocktail of neurohormones [17-26]. Neuromodulator oligopeptides have specific effects on reproductive organs. For example, APGWamide contributes to peristalsis in the vas deferens of the great pond snail Lymnaea stagnalis $[17,18]$. This hormone also has been implicated as a spawning stimulant in the male tropical abalone Haliotis asinina [27]. In L. stagnalis, the caudodorsal cell hormone $(\mathrm{CDCH})$ contributes to oocyte release, egg packaging and oviposition [19,28], while the dorsal body hormone (DBH) regulates vitellogenesis and female cell maturation [29]. By comparison, the schistosomin peptide hormone inhibits reproduction by inhibiting $\mathrm{CDCH}$ and $\mathrm{DBH}[20]$.

Amongst broadcast spawning molluscs, there is less known about hormonal regulation of reproduction. $H$. asinina has a highly predictable spawning cycle, allowing for a detailed analysis of the factors influencing reproduction and spawning. In the wild, $H$. asinina spawns fortnightly in a highly predictable and synchronised manner through the reproductive season, which on the southern Great Barrier Reef lasts about 6 months [7,12]. Spawning is tightly correlated with spring tides associated with new and full moons, with spawning events occurring within an hour of the evening high tide [7]. Final oocyte maturation and release from gonadal connective tissue (trabeculae) occurs about $18 \mathrm{~h}$ earlier, around the time of the morning low tide [12]. The timing and height of this low tide has been implicated in controlling the cascade of events that lead to spawning [7]. In addition, abalone removed from natural lunar and tidal cycles (i.e. transported to an indoor closed system away from the sea) maintain synchronous, fortnightly spawnings for at least two cycles (i.e. one month), indicating that endogenous rhythms play a regulating role and that the natural spawning cycle can not be disrupted by removing $H$. asinina from its natural habitat [7].
Here, we describe how $H$. asinina orthologues of four well established molluscan reproduction-related neuropeptide-encoding genes - APGWamide, myomodulin, FMRFamide and schistosomin - and three additional neuropeptide genes - whitnin, haliotid growth associated peptide (HGAP), and molluscan insulin-related peptide (MIP) - vary in expression in the cerebral and pleuropedal ganglia (hereafter collectively referred to as the anterior ganglia) throughout the two week $H$. asinina reproductive cycle. Using quantitative reverse transcription-polymerase chain reaction (qPCR), we compare the expression levels of these genes in male and female anterior ganglia. In the two days prior to and the day following the spawning event, all neuropeptide genes were differentially expressed, with some showing peaks in expression at the spawning event and others $12 \mathrm{~h}$ prior to or after the event. In many cases, expression levels differed in male and female ganglia for a given gene. These results are consistent with the neurohormones secreted from anterior ganglia playing a role in controlling a synchronised broadcast spawning event in $H$. asinina.

\section{Results}

Sequence and post-translational processing of HasAPGWamide, Has-Myomodulin and Has-Whitnin

A single, partial-length clone encoding Has-APGWamide was identified from the reproductively active anterior ganglia vs. non-reproductively active anterior ganglia (RA/NRA) suppression subtractive hybridisation (SSH) library (see methods), and its sequence was extended by rapid amplification of cDNA ends (RACE). Isolated full-length sequence length was 969 bp [GenBank: JN606061], encoding a 222 residue prepropeptide (Figure 1A). Has-APGWamide is predicted to encode 10 copies of APGWamide, 6 connecting peptides (CPs), and a C-terminal peptide, and is most similar to the Aplysia californica APGWamide gene [30] (Figure 1B); H. asinina CPs are numbered using the system for Aplysia [31]. Examination of anterior ganglia sections by matrixassisted, laser desorption-ionisation time-of-flight mass spectrometry (MALDI-TOF-MS) (Figure 1C.) revealed masses consistent with APGWamide $(\mathrm{m} / \mathrm{z}$ 428.5) in all sections examined (cf. [32]), and an acetylated CP3 peptide $(\mathrm{m} / \mathrm{z} 1124.2)$ was found in all sections except the cerebral commissure. By ganglionic region, observed $\mathrm{m} / \mathrm{z}$ were: left cerebral ganglia section 1 (LG1): APGWamide: 427.7, 428.7, 428.8, 428.9, 429; CP3: 1124.8; left cerebral ganglia section 2 (LG2): APGWamide: 427.7, 428, 428.7, 428.9; CP3: 1124.7, 1124.8; cerebral commissure (CC): APGWamide: 427.7, 428.7; right cerebral ganglia section 1 (RG1): APGWamide: 427.7, 428.7, 428.9, 429, 429.1; CP3: 1124.7, 1124.8; right cerebral ganglia section 2 (RG2): APGWamide: 427.7, 428.7, 428.9, 429, 429.1; CP3: 1124.7, 
1124.8; pleuropedal ganglia middle section (PGM): APGWamide: 427.7, 428.7, 428.9, 429; CP3: 1124.8, 1125.1.

Two partial-length sequences encoding the HasMyomodulin transcript were found in the RA/NRA SSH library. Has-Myomodulin sequence was extended in silico by alignment with previously discovered expressed sequence tags (ESTs) ([GenBank:GT277631, GenBank: GT275969, GenBank:GT273228, GenBank:GT067419, GenBank:GT067304]; [36,37]). The isolated final sequence length was 1526 bp (Figure 2A, [GenBank:JN606062]), encoding a well-conserved 297 residue prepropeptide (Figure 2B), which was most similar to the $A$. californica Myomodulin 1 prepropeptide (BLASTp E-value 2e-49) [38]. Has-Myomodulin encodes 7 copies of PMNMLR Lamide, two copies of ALGMLRLamide, and single copies of each of PVNMLRLamide, ALSMLRLamide, GGLNMLRLamide, GLNMLRLamide, and GLQMLR Lamide. Masses matching the most commonly encoded myomodulin PMNMLRLamide ( $\mathrm{m} / \mathrm{z}$ 873.1) were found in the anterior ganglia by MALDI-TOF-MS (Figure 2C). Observed m/z, by section, were: LG1: 872.8; RG1: 872.8, 872.9; RG2: 872.9; PGM: 872.8.

The RA/NRA SSH library revealed two partial-length whitnin homologues, extended in silico using previously discovered EST sequences ([GenBank:GD241801, Gen Bank:GT276135, GenBank:GT276859]; [37,40]) to produce a final sequence of 833 bp [GenBank:JN606063] that encodes a prepropeptide of 114 amino acids (Figure 3A). Has-Whitnin dibasic cleavage sites and primary structure appear conserved (Figure 3B), with greatest similarity to A. californica whitnin [41]. The whitnin gene has previously been referred to as the SPTR gene in Lymnaea stagnalis [42] and as a PKYMDT or proctolin gene in Lottia gigantea [34]. We select here the name Whitnin to describe the gene and the entire encoded peptide, with SPTR, ERYM and PKYMDT nomenclature here used to describe relevant sub-regions (see Figure 3B). Posttranslational processing is predicted to produce peptides including an SPTR homologue, the SPTR derivatives LPA DEamide and LDEASLAAE, the conserved PKYMDT peptide proposed as the molluscan homologue of Proctolin [34], and a processed ERYM peptide (Figure 3B). Anterior ganglia examination by MALDI-TOF-MS revealed masses consistent with LPADEamide (m/z 542.6), also its SPTR peptide precursor LPADEGRLDEASLAAE $(\mathrm{m} / \mathrm{z}$ 1656.8 Da). Further masses matching a post-translationally modified Has-ERYM peptide (MYMGICMRQSHNHFI PYPCMRSamide); both disulphide bonded (m/z 2700.2) and non-disulphide bonded (m/z 2702.3) versions of the same peptide were observed (Figure $3 \mathrm{C}$ ). By ganglia section, observed masses were m/z: LG1: SPTR: 1656.6; ERYM (cysteines bonded) 2699.9, 2700.9; ERYM (cysteines unbonded): 2702; RG1: LPADEamide: 541.7; RG2: LPADEamide: 541.6, 541.7; ERYM (linked cysteines):
2699.9, 2700; ERYM (unbonded): 2701.9, 2702; PGM: LPADEamide: 542.8; SPTR: 1656.5; ERYM (linked cysteines): 2699.9, 2700.9.

\section{Neuropeptide genes have dynamic and idiosyncratic expression profiles during the $\mathbf{H}$. asinina spawning cycle}

To characterise neuropeptide gene expression over the course of the reproductive cycle, we took anterior ganglia from freshly caught groups of male and female $H$. asinina throughout their two week reproductive cycle $[7,12]$. These samples were collected at the same time each day (2200), except half-day samples, which were collected at 1000. This resulted in all samples taken within 2 days of the spawning event being taken within $1 \mathrm{~h} 45 \mathrm{~min}$ of the high tide. For each time point, 4 gravid males and 4 gravid females were sampled; with 10 time points, $80 \mathrm{H}$. asinina from Heron Island Reef were used in this study. Analysis of transcript abundance of seven neuropeptide-encoding genes - Has-APGWamide, Has-Myomodulin, Has-Whitnin, Has-FMRFamide, HasSLP, Has-MIP and Has-HGAP - over the reproductive cycle by $\mathrm{qPCR}$ revealed that each gene has a unique and sexspecific expression profile (Figures 4, 5, 6). In general, expression profiles were consistent across individual males and females for a given gene, although relative gene expression levels did vary between individuals. Standard errors in Figures 4, 5, 6 depict biological variation.

Has-APGWamide transcript abundance peaked on the day of spawning in both males and females (Figure 4A), with all individuals surveyed having remarkably similar expression profiles. Male and female Has-APGWamide expression profiles tracked closely throughout the spawning cycle, although males had a secondary prespawning peak in expression on $-3 \mathrm{~d}$, while females had a secondary peak on $-2 \mathrm{~d}$ (Figure 4A; Figure 6), which resulted in a significant difference in expression levels between the sexes on $-3 \mathrm{~d}$. There were no detectable differences in male and female expression profiles during the two days leading up to the spawning event, and the day after (Figure 6).

Has-Myomodulin expression levels varied the most between individual males and females, and also between sexes (Figure 4B). Male expression levels were maximal at the time of spawning, while female expression levels peaked twice, at $-2 \mathrm{~d}$ and $12 \mathrm{~h}$ before spawning, but because of the large biological variation, one significant difference in expression was observed.

In contrast, changes in Has-Whitnin transcript abundance during the semi-lunar spawning cycle were very consistent between individual male and females, with male expression levels reaching maximal levels over a $24 \mathrm{~h}$ period surrounding spawning (Figure 4C). As in Has-Myomodulin, females had highest expression of $12 \mathrm{~h}$ before spawning, around when the oocytes are releasing from the gonadal extracellular matrix. 
(See figure on previous page.)

Figure 1 Characterisation of Has-APGWamide. (A) Nucleotide and predicted amino acid sequence of Has-APGWamide (nucleotide and amino acids are numbered on left). A predicted signal sequence is underlined, and predicted dibasic and tribasic cleavage site residues are boxed. The Has-APGWamide qPCR primers correspond to the nucleotides 750-771 and 830-853, identified here in bold. (B) Multiple sequence alignment of molluscan APGWamide prepropeptide sequences. Shading to four levels shows conservation as per Nicholas et al. (1997) [33]. The start of each H. asinina APGWamide is indicated with an asterisk. Haliotis, H. asinina [GenBank:JN606061]; Lottia, Lottia gigantea [34]; Lymnaea, Lymnaea stagnalis ([GenBank:1811269A], [35]); Aplysia, A. californica ([GenBank: NP_001191561], [30]). (C) Schematic representation of H. asinina anterior ganglia showing regions analysed by MALDI-TOF-MS. Representative mass peaks were identified that match APGWamide $(\mathrm{m} / \mathrm{z}$ 428.9) and the acetylated CP3 peptide Ac-TLDILEDYT (m/z 1124.8) (right). Signal, signal sequence; LG1, left cerebral ganglia region 1; LG2, left cerebral ganglia 2; RG1, right cerebral ganglia 1; RG2, right cerebral ganglia 2; CC, cerebral commissure; PGM, pleuropedal ganglia middle; Ac, acetylation; amide, amidation; $\mathrm{m} / \mathrm{z}$, mass to charge ratio.

In both males and females, Has-FMRFamide expression increased from the lowest detectable levels at $36 \mathrm{~h}$ prespawn to the highest levels at $12 \mathrm{~h}$ postspawn (Figure 4D). Unlike males where transcript abundance continually increased during this period, females exhibited a drop in expression at the time of spawning. In both sexes, mRNA levels dropped significantly between 12 and 24 h postspawn.

Has-SLP transcript abundance was relatively low overall; lowest levels of expression occurred $24 \mathrm{~h}$ pre- and post-spawn in both males and females, with expression increasing at spawning; female expression plateaued over the $24 \mathrm{~h}$ period surrounding the spawning event (Figure 5A). Has-SLP expression in females was mostly higher during the interspawn period $(+1 \mathrm{~d}$ to $-2 \mathrm{~d})$ than during the time around spawning.

Has-MIP expression peaked in males at the time of spawning, while in females it remained relatively constant from $-3 \mathrm{~d}$ to $+0.5 \mathrm{~d}$ (Figure $5 \mathrm{~B})$. There was notable variation in expression levels between individual males and females, particularly just before, at and after the spawn.

Has-HGAP expression levels were also very low throughout the spawning cycle, with relatively high variation in expression between individuals (Figure 5C). As for Has-SLP and Has-MIP, Has-HGAP gene expression levels were not markedly higher over the spawning period compared to the interspawn period.

\section{Discussion}

Unlike most molluscs and broadcast spawning marine invertebrates, Haliotis asinina has a highly predictable spawning cycle. Although previous studies established that semilunar synchronous spawning in $H$. asinina is likely the result of tidal entrainment of endogenous rhythms and that these endogenous rhythms persist in captivity for up to six weeks $[7,12]$, the underlying molecular mechanisms controlling this process have not been previously explored. In non-spawning molluscs, neuropeptides secreted from anterior ganglia play a regulatory role in reproduction (e.g. [17-26]). Here we demonstrate that orthologues of these (APGWamide, myomodulin, FMRFamide and SLP) and other (whitnin, MIP and HGAP) neuropeptides are differentially expressed in the anterior ganglia of $H$. asinina during the spawning cycle. Although we recognise that this work is essentially correlative in nature and cannot confirm corresponding alterations in peptide production at this time, the described changes in gene expression are consistent with at least some of these genes playing a role in controlling the reproductive physiology and spawning in this gastropod.

\section{Post-translational processing produces peptides from Has-APGWamide, Has-Myomodulin and Has-Whitnin}

Multiple individual peptide neuromodulators are derived from a common propeptide precursor by post-translational cleavage and subsequent modification [43]. As for other $H$. asinina neuropeptides, namely Has-SLP, Has-MIP, Has-HGAP [44] and Has-FMRFamide [45], we demonstrate here that prohormones encoded by HasMyomodulin, Has-APGWamide and Has-Whitnin are processed to yield a repertoire of small neuropeptides. The Has-Myomodulin gene encodes 7 copies of the highly conserved PMNMLRLamide, compared to 9 to 10 copies of the corresponding myomodulin in other characterised gastropods [34,38,39]. PMNMLRLamide is present in 4 out of $6 H$. asinina ganglia regions, indicating widespread anterior ganglia expression.

Has-APGWamide encodes 10 APGWamide peptides, similar to the 9 to 10 found in L. stagnalis, A. californica and L. gigantea $[31,34,35]$. The Has-APGWamide region corresponding to the proposed A. californica peptide neurotransmitter CP3 (also known as Cerebral Peptide 1 ; $[30,31]$ is poorly conserved compared to other molluscan CP3 regions. However, masses consistent with APGWamide and the Has-CP3 peptide (sequence AcTLDILEDYT) have been detected by MALDI-TOFMS, thus supporting our predicted processing model. The detection of APGWamide in all anterior ganglia, and of Has-CP3 in all regions except the $\mathrm{CC}$, indicates that these peptides are widely distributed in the anterior ganglia.

In comparison to APGWamide and myomodulin, whitnin is relatively poorly studied in molluscs (see [34]); a homologue is present in the annelid leech Hirudo 
(See figure on previous page.)

Figure 2 Characterisation of Has-Myomodulin. (A) Nucleotide and predicted amino acid sequence of Has-Myomodulin (nucleotide and amino acids are numbered on left). A predicted signal sequence is underlined and predicted monobasic and dibasic cleavage sites are boxed. Predicted myomodulins cleaved from the precursor are shaded. Has-Myomodulin qPCR primers described in Table 1 correspond to nucleotides $1034-1057$ and 1122-1144, here shown in bold. (B) Multiple sequence alignment of molluscan myomodulin prepropeptide sequences. Shading is to 4 levels, and indicates conservation as described in Nicholas et al. (1997) [33]. Asterisks indicate the start of H. asinina myomodulins. Haliotis, H. asinina [GenBank:JN606062]; Lottia, Lottia gigantea (Joint Genome Institute, Protein ID 159404); Lymnaea, Lymnaea stagnalis ([GenBank:X96933]; [39]); Aplysia, A. californica ([GenBank:S64300], [38]). The C-terminal Q has been removed from the Aplysia sequence. (C) Schematic representation of H. asinina anterior ganglia showing regions analysed by MALDI-TOF-MS. Identification by MALDI-TOF-MS of the most commonly encoded myomodulin PMNMLRLamide in regions of $\mathrm{H}$. asinina anterior ganglia. Peak shown is representative of PMNMLRLamide (m/z 872.9) (right).

Signal, signal sequence; LG1, left cerebral ganglia region 1; LG2, left cerebral ganglia 2; RG1, right cerebral ganglia 1; RG2, right cerebral ganglia 2; CC, cerebral commissure; PGM, pleuropedal ganglia middle; amide, amidation; $\mathrm{m} / \mathrm{z}$, mass to charge ratio.

medicinalis [46]. The post-translational processing of the L. stagnalis whitnin yielded two peptides - SPTR and ERYM - with two further probable intervening peptides [42]. Veenstra (2010) [34] posits that one of those intervening peptides - PKYMDT, which follows the SPTR region - may be the molluscan Proctolin homologue. Encoded peptide positions within the Has-Whitnin propeptide appear to be conserved, although PKYMDT peptide was not detected by MALDI-TOF-MS in the current study.

The L. stagnalis SPTR peptide is located between the signal peptide and the first conserved dibasic cut site, and is cleaved from the propeptide in an unmodified form [42]; the SPTR model appears to be conserved (cf. A. californica, L. gigantea). The evident Has-Whitnin propeptide cleavage at $\mathrm{Arg}_{31}$, and subsequent C-terminal amidation of the resulting LPADEG peptide to form the novel LPADEamide, is detected by MALDI-TOF-MS in 3 out of 6 anterior ganglia regions (RG1, RG2 and PGM). The detection of an uncleaved SPTR peptide in two regions examined (LG1 and PGM) likely represents immature peptide, although we cannot exclude the possibility that the $H$. asinina SPTR peptide is secreted and has a function discrete from that of LPADEamide.

The L. stagnalis ERYM peptide is C-terminally amidated, with a single internal disulphide bond [42]. Amidated $H$. asinina ERYM peptide are present in three anterior ganglia (LG1, RG2, and PGM), consistent with the L. stagnalis model. The detection of non-disulphide bonded, amidated ERYM versions (LG1 and RG2) likely represents either artifactual reduction of the disulphide bond during MALDI-TOF-MS or an immature form of the ERYM peptide.

\section{Upregulation of Has-APGWamide, Has-Myomodulin, Has-Whitin and Has-FMRFamide around oocyte maturation or spawning}

All seven neuropeptide genes analysed in this study are differentially expressed across the semilunar spawning cycle of $H$. asinina, with most having the lowest levels of expression prior to and after spawning, and high expression levels occurring at, just before or just after spawning (Figure 6). That said, no two gene expression profiles were the same, and expression levels relative to the consistently-expressed reference genes varied markedly, from less than 0.05 times the reference genes (Has-HGAP) to nearly 90 times the reference genes (Has-Whitnin).

The increase in expression of Has-APGWamide at the time of spawning in male and female $H$. asinina is consistent with the established role of APGWamide in molluscan reproduction, particularly its control of muscles in both male and female gonads and sex organs [17,18,47-49]. The peak in $H$. asinina female expression at spawning, taken together with observations in other molluscs, suggests that APGWamide may contribute to the modulation of the induction and regulation of female spawning. Female $H$. asinina spawn with numerous distinct contractions over a period of approximately 5-15 minutes (personal observations). Based on known functions [49], we speculate that APGWamide may be involved in muscle relaxation between contractions. The observed role of APGWamide in triggering spawning in $H$. asinina males [27] may also relate to muscle relaxation between spawning contractions.

Has-Myomodulin expression in the anterior ganglia of male and female $H$. asinina varies markedly between individuals, which made it difficult to detect significant differences in expression between stages of the spawning cycle. Nonetheless, anterior ganglia expression peaks at the time of spawning in males and when oocytes dissociate from the female ovary $(-0.5 \mathrm{~d})$. Although it is unclear what the precise role of Has-Myomodulin has in reproduction, in other molluscs myomodulins have a well-established role in neuromodulating a variety of reproductive processes $[21,23,25]$. Myomodulins also have a well-documented role in feeding [50-55]. Interestingly, we have previously shown that expression of Has-Myomodulin in the anterior ganglia is also correlated with feeding status in aquaculture [36]. Indeed, variation in individual foraging success may explain the high individual variation in expression of this gene in this study. However, as all animals were 


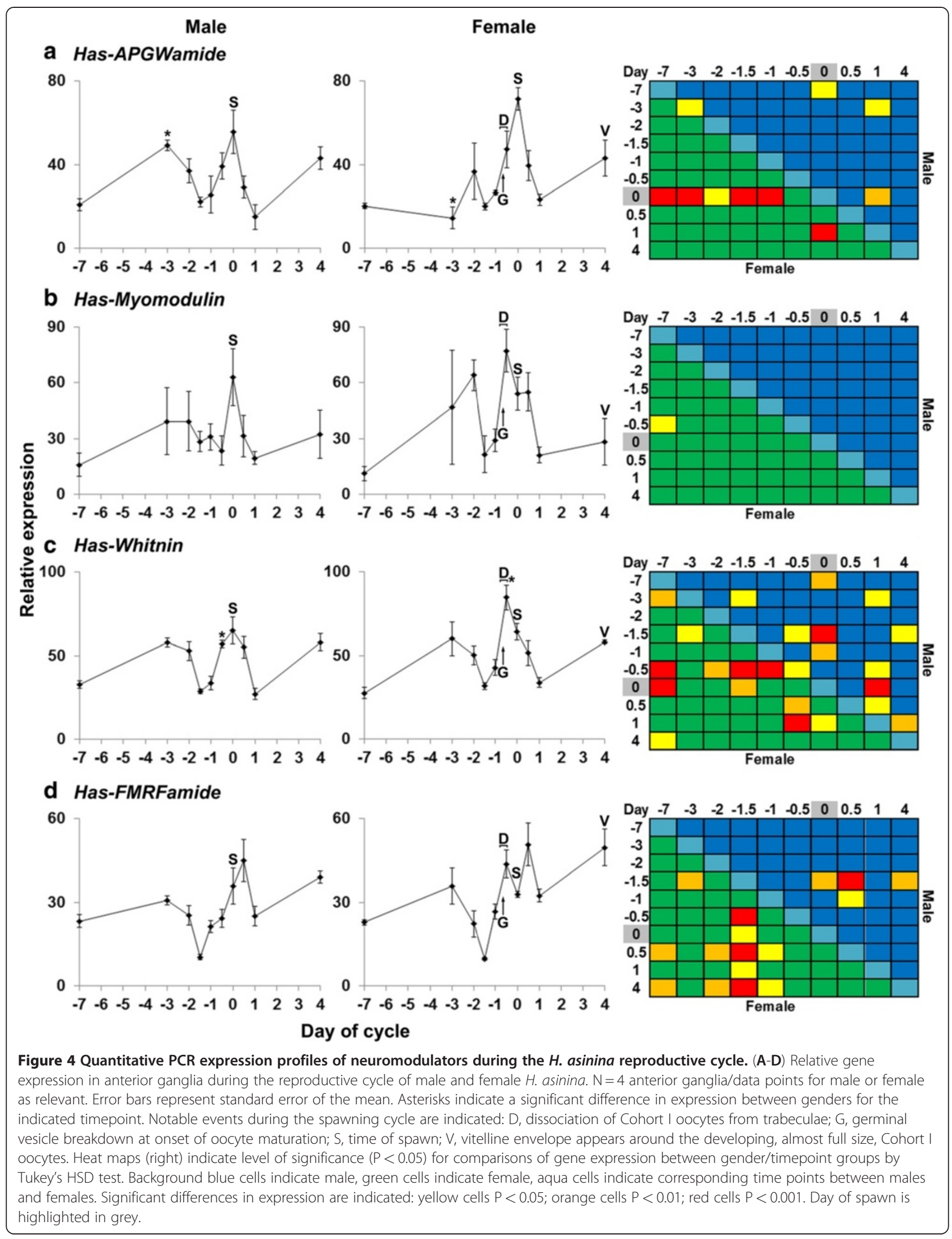




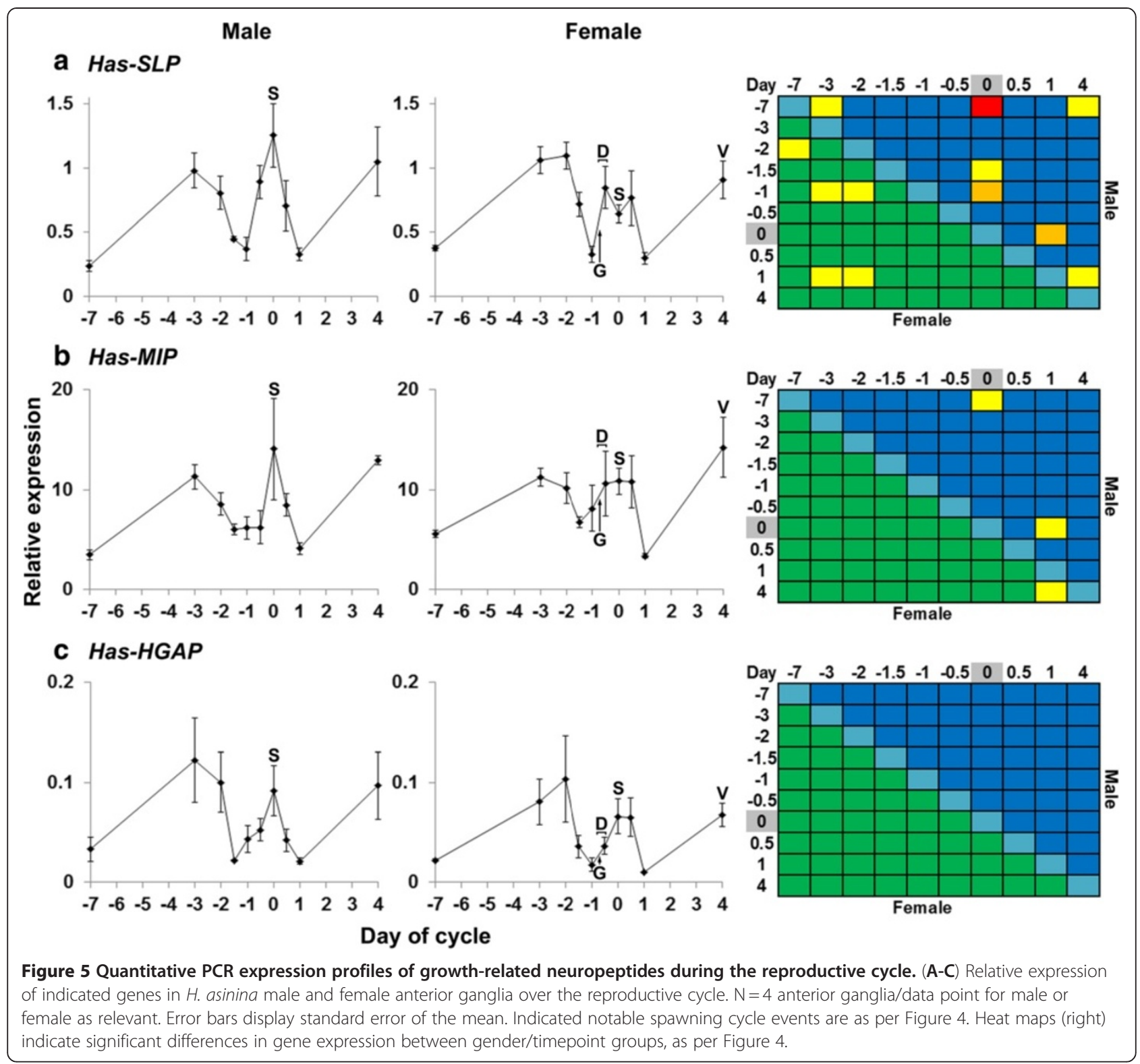

collected from the wild, pre-experiment feeding regimes were not known.

We observed many significant differences in HasWhitnin gene expression over the reproductive cycle in both males and females. As the relative expression level of Has-Whitnin correlates tightly with the stage of the spawning cycle, this gene may be an excellent expression marker for the spawning cycle. Given the established neuromodulatory role of whitnin-derived peptides [34,42,56], we suggest that Has-Whitnin contributes to the control of reproduction. Has-Whitnin expression in female $H$. asinina peaks 12 hours prior to spawning, at which time oocytes release from the gonadal trabeculae [12]. In contrast, male expression peaks at time of spawn. These and other sex-specific differences in Has-Whitnin gene expression in the reproductive cycle suggest a gender-specific role for this gene.

FMRFamide is widely distributed in the animal kingdom. Its function is diverse, and includes modulation of feeding behaviour [57], retinal response to light [58], sexual maturation [58], apoptosis [59], osmoregulation [60-63], and regeneration [64-66]. Has-FMRFamide [45] expression levels change dramatically over the semilunar spawning cycle, and between males and females. The gender-specific reproductive roles of FMRFamide in closely related molluscs $[17,67-72]$ provides a compelling argument that Has-FMRFamide is a reproduction-related gene. In particular, the peak in female Has-FMRFamide 


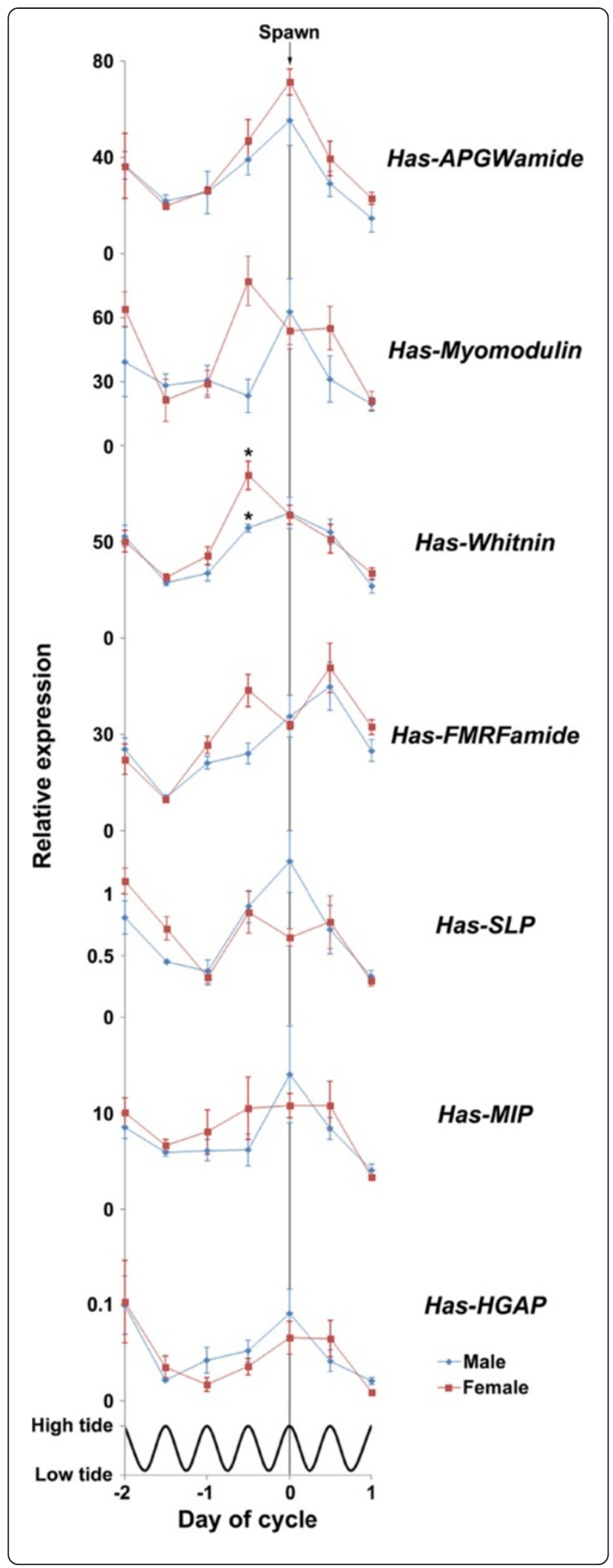

Figure 6 Comparison of quantitative PCR expression profiles surrounding the spawning event. Male expression shown in blue ( $N=4$ anterior ganglia/data point), female expression shown in red ( $N=4$ anterior ganglia/data point). Error bars display standard error of the mean. Asterisks indicate a significant difference in expression between genders for the indicated timepoint. Tidal cycle is shown; all timepoints were taken at high tide.

expression at $-0.5 \mathrm{~d}$, followed by a notable reduction at time of spawn, is consistent with known reproductive roles of FMRFamide in other molluscs.

FMRFamide has a demonstrated role in the inhibition of egg-laying in the molluscs L. stagnalis and A. californica; it prevents secretion of the hormones that trigger egg laying $[67,69]$. We suggest that the peak in Has-FMRFamide expression at Day -0.5 may reflect $H$. asinina use of FMRFamide to inhibit precocious spawning. The subsequent drop in female expression at time of spawn, which is highly consistent among individuals, is consistent with this proposition. Such FMRFamide-mediated inhibition of gamete release has so far been demonstrated to pertain only to females. Indeed, given that L. stagnalis and A. californica are hermaphroditic and produce male and female gametes at different times $[9,10]$, it can be assumed that there exist discrete mechanisms for male and female gamete release. The presence of a female peak and lack of a corresponding male peak in Has-FMRFamide expression at Day -0.5 is therefore consistent with the notion that FMRFamide is a functionally conserved temporal regulator of female, but not male, gamete release in gastropods. There is a peak in both male and female FMRFamide expression at $0.5 \mathrm{~d}$, which may reflect a role for FMRFamide in recovery from spawning and regeneration of the gonad. In females, phagocytosis of unspawned mature oocytes and the rebuilding of trabeculae are underway at this time [12]. FMRFamide is known to be involved in regenerative processes, including the acceleration of healing $[64,65]$, stimulation of protein and nucleic acid synthesis [73], neural regeneration [66], and the regulation of apoptosis [59].

The biological significance of the marked and transient decrease in Has-FMRFamide, Has-APGWamide, HasMyomodulin (female only), Has-Whitnin and Has-HGAP (male only) expression levels $36 \mathrm{~h}$ before spawning (Figure 6) is unknown. This general decrease in expression corresponds to the morning high tide the day before the spawning event and may signify some time-keeping mechanism linked to a threshold tidal level and endogenous rhythms, as previously proposed [7]. In the next $24 \mathrm{~h}$, the oldest cohort of oocytes in the ovary will undergo germinal vesicle breakdown and dissociate from ovary trabeculae, ready to be spawned [12]. Interestingly, a consistent drop in gene expression in these and the other genes 
occurs one day after the spawn (Figure 6) suggesting that this might be another time-keeping event, triggering the synchronisation of oogenesis and possibly spermatogenesis for the next spawning event in approximately two weeks. The maintenance, for at least a month, of the synchronous spawning cycle in $H$. asinina that have been removed from the natural environment [7] indicates endogenous signals can maintain rhythmicity without exposure to tide or lunar cycle.

\section{Has-SLP, Has-MIP and Has-HGAP exhibit variable but low expression levels during the spawning cycle}

Has-SLP, Has-MIP and Has-HGAP exhibit expression profiles similar to that observed for the other neuropeptide genes, with lowest levels of expression tending to be 2 days before and a day after the spawning event (Figure 6). However, Has-SLP, Has-MIP and Has-HGAP are expressed at much lower levels than the other four genes, and do not exhibit such large differences in transcript abundance between spawning and interspawning stages. Together, these observations are consistent with these three neuropeptide genes having a less important role in controlling spawning.

Schistosomin inhibits molluscan reproduction by inhibiting the production and secretion of female reproductive hormones [20,74-77]. This role appears to be conserved in gastropods that copulate (L. stagnalis, L. ovata, Biomphalaria glabrata, Biomphalaria pfeifferi, and Bulinus truncatus) [20,74-79]. Other non-reproductive roles for schistosomin also have been postulated, including promotion of growth via triggering the secretion of MIP $[20,79]$ and in larval development $[80,81]$. In $H$. asinina, a gene encoding a schistosomin-like peptide (Has-SLP) was recently isolated and found to be upregulated in fastgrowing juvenile abalone [44]. The high expression of HasSLP in the interspawn period reported here is consistent with a conserved role for Has-SLP in the inhibition of female reproductive processes. Based on expression profiles (Figure 6), Has-SLP may play a different role in males than in females, although details of this are unknown at this time.

Molluscan insulin-related peptides (MIPs) are molluscan peptide hormones thought to promote growth and regulate nutrient uptake $[19,20,82-86]$. There is an established relationship between the reproduction-related hormone schistosomin and MIP release: L. stagnalis schistosomin causes MIP release, resulting in growth of the animal [20]. However, we have found that the Has-MIP gene is down-regulated in fast growing animals compared to slow growers [44]. In the present study, Has-MIP expression did not vary markedly through the spawning cycle, although there was a decrease in transcript abundance at -1.5 and $+1 \mathrm{~d}$, as observed for many of the other genes. Interspawn expression levels were high or similar to the expression levels around the time of spawning, suggesting a minor role for this peptide in the control of spawning

The HGAP gene was first found in a $H$. asinina anterior ganglia SSH library created from well-nourished against food-deprived animals ([36]; [GenBank:GT067343]). Further characterisation has revealed that Has-HGAP encodes a double-chain secreted peptide and is expressed in all tissues examined except the gill [44]. To date, HGAP has only been found in $H$. asinina. Although it is unknown whether Has-HGAP actively promotes growth as a regulatory hormone, Has-HGAP expression is upregulated in fast growing $H$. asinina compared to slow growing individuals [44]. Has-HGAP expression overall is the lowest of all genes surveyed in this study and, as for Has-MIP, is highest during interspawn periods. In the case of both these genes, there was marked individual variation in expression levels, rendering it difficult to infer much from these expression profiles.

\section{Conclusions}

We report here the sequences of the neuromodulatorencoding genes Has-APGWamide, Has-Myomodulin and Has-Whitnin, and describe the post-translational processing of their encoded peptides. Comparisons to molluscan orthologues indicate that processing of the proneuropeptides is well conserved in all cases. QPCR analysis reveals that expression in the anterior ganglia of HasAPGWamide, Has-Myomodulin and Has-Whitnin, as well as another neuromodulator-encoding gene HasFMRFamide, varies across the $H$. asinina reproductive cycle. Peaks in the expression levels of these genes correspond to events associated with spawning, including oocyte maturation and dissociation from the ovary. Perhaps most notably, Has-FMRFamide expression, along with Has-APGWamide, Has-Myomodulin and Has-Whitnin, is suggestive of a synchronisation mechanism in the reproductive cycle, 36 hours prior to spawning. The temporal map of expression of the seven candidate reproduction-related genes provided in this study will assist future endocrinological studies into molluscs and other marine invertebrates that synchronously release their gametes in a broadcast spawning event. In particular, this study presents a range of neuropeptide candidates to investigate the control of spawning in species with less tractable and predictable spawning, including those of commercial importance.

\section{Materials and Methods \\ Animals}

Adult male and female $H$. asinina (gravid and ranging from approximately 12 to $20 \mathrm{~cm}$ in length) that were used for the gene expression analyses were collected from 
Heron Island Reef (Queensland, Australia) under permit, and kept in flow-through seawater tanks with water obtained from the reef flat from where the abalone were collected. For the analysis of gene expression during the spawning cycle, abalone were collected no more than three days before sacrificing. Animals used for peptidomic analyses were collected from Heron Island reef and transported to Bribie Island Research Centre (Queensland Primary Industries and Fisheries, Department of Employment, Economic Development and Innovation), and kept in an inside tank with a 12-hour light/dark cycle. Collected animals were fed to satiety on local algae from Heron Island Reef. Animals housed at Bribie Island Research Centre were fed to satiety with Gracillaria edulis, and an artificial food purchased from Adam \& Amos Abalone Foods Pty. Ltd. [87].

Sequence isolation, extension, identification and analysis RNA isolation, cDNA synthesis and amplification, SSH, cloning, sequencing, and in silico sequence extension were carried out as described in York et al. 2010 [36]. $\mathrm{SSH}$ utilised anterior ganglia from two reproductively active (RA) and two non-reproductively active (NRA) adult $H$. asinina as Tester and Driver samples, respectively. Where appropriate, the SMART ${ }^{\mathrm{m}}$ RACE cDNA Amplification Kit (Clontech, Mountain View, California) was used to obtain entire coding sequence, as per manufacturer's protocols.

To identify related sequences, a BLASTx search against the NCBI database $[88,89]$ was performed, with a stringency cutoff e-value of $10^{-6}$. Neuropeptide posttranslational processing was predicted from translated sequence using the NeuroPred [90,91], SignalP [92,93] and SIG-Pred [94] programs. Multiple sequence alignments were done with the Molecular Evolutionary Genetics Analysis software version 4.0 program (MEGA4) [95], using the ClustalW algorithm [96]. Shading of multiple sequence alignments was performed using GeneDoc Version 2.7.000 [33].

\section{Matrix-Assisted Laser-Desorption/Ionisation-Time of Flight} Mass Spectrometry (MALDI-TOF-MS)

MALDI-TOF-MS was performed as described in Cummins et al. (2009) [32]. Briefly, anterior ganglia were removed from 14-month old $H$. asinina, rinsed in aqueous MALDITOF-MS matrix solution $[20 \mathrm{mg} / \mathrm{ml}$ 2,5-dihydroxy benzoic acid (Sigma-Aldrich, St. Louis, Missouri) in $30 \%$ acetonitrile $/ 0.1 \%$ trifluoroacetic acid], sectioned, and desheathed. Each section was then torn into tiny fragments in matrix solution using dissection forceps. Tiny fragments $(<1 \mathrm{~mm})$ of each section were placed on a MALDI-TOFMS plate in $0.5 \mu \mathrm{L}$ matrix solution. A Voyager-DE STR Biospectrometry Workstation (Applied Biosystems, Foster City, California), with $\mathrm{N}_{2}$ laser and pulsed ion extraction accessory was used to analyse the fragments, with 500 shots in reflectron mode. Masses were taken as identified if within $1 \mathrm{Da}$ of predicted average mass.

\section{Reproductive cycle expression analysis of selected genes by qPCR}

For each point in the time series, anterior ganglia were dissected from 4 anaesthetised male and female abalone, each which was haphazardly chosen from the pool of previously collected gravid adults, and stored in RNALater at $-80^{\circ} \mathrm{C}$ as previously described [36]. Total RNA was extracted using Tri Reagent (Sigma-Aldrich, St. Louis, Missouri), and reverse transcribed using SuperScript III Reverse Transcriptase (Invitrogen, Carlsbad, California), as per manufacturers' instructions. Oligonucleotide primers for qPCR were either those used in previous studies $[36,44]$, or were designed using the Primer3 program $[97,98]$ (Table 1). Relative transcript abundance in anterior ganglia was measured between male and female time points taken throughout the course of the 14day $H$. asinina reproductive cycle using a Roche Lightcycler $^{\circledR} 480$ II qPCR machine with Lightcycler ${ }^{\circledR} 480$ SYBR Green I Master (Roche, Penzberg, Upper Bavaria). The reference genes Has-UEST1506, Has-NACA, and

\section{Table 1 Oligonucleotide primers for qPCR}

\begin{tabular}{|c|c|c|}
\hline Target gene & $\begin{array}{l}\text { Primers } \\
\text { ( } F=\text { forward and } R=\text { reverse) }\end{array}$ & $\mathrm{Tm}$ \\
\hline \multirow[t]{2}{*}{ Has-APGWamide } & F: TCTGAGGCTGGGAGATCAAAGG & $68^{\circ} \mathrm{C}$ \\
\hline & R: ACGTGTTTGGGAACATCCAGTAGG & \\
\hline \multirow[t]{2}{*}{ Has-Whitnin } & F: CACGCCAAGAGGACTITGAGATGG & $68^{\circ} \mathrm{C}$ \\
\hline & R: GGGTATGGGATGAAGTGGTTGTGTG & \\
\hline \multirow[t]{2}{*}{ Has-Myomodulin } & F: ACGGTCGGACGAGAAAGTTGATGG & $68^{\circ} \mathrm{C}$ \\
\hline & R: TGATGGGTTTGTTGGGAGGGATG & \\
\hline \multirow[t]{2}{*}{ Has-FMRFamide } & F: TTCGGGAAGCGAGATTCTGGTG & $68^{\circ} \mathrm{C}$ \\
\hline & R: GGTGGATGTGAAACAGCGAACAGTC & \\
\hline \multirow[t]{2}{*}{ Has-SLP } & F: TCGTCCTCATCGCTCTCGTTGTT & $69^{\circ} \mathrm{C}$ \\
\hline & R: GGAGCCGTTGGAAATGCAGAAG & \\
\hline \multirow[t]{2}{*}{ Has-MIP } & F: CAAGCGGACGAGTGAACAAGG & $67^{\circ} \mathrm{C}$ \\
\hline & R: TTGCTCTTACAGCGTCTAGCATGG & \\
\hline \multirow[t]{2}{*}{ Has-HGAP } & F: CTGTGCATTCTCCTTGTCGTAGTCG & $68^{\circ} \mathrm{C}$ \\
\hline & R: GCTCATGTAGCCGAATGATTCTTCC & \\
\hline \multicolumn{3}{|l|}{ Reference genes } \\
\hline \multicolumn{3}{|c|}{ (Williams et al., 2009) } \\
\hline \multirow[t]{2}{*}{ Has-Ubiquitin } & F: TGGCAAGCAGTTGGAAGATGGT & $57^{\circ} \mathrm{C}$ \\
\hline & R: CAGTTGTACTTGGAGGCCAGGAT & \\
\hline \multirow[t]{2}{*}{ Has-NACA } & F: TGTCGCAAGCCAACGTTTCA & $57^{\circ} \mathrm{C}$ \\
\hline & R: GACAGCATGTTCAGCACTGGT & \\
\hline \multirow[t]{2}{*}{ Has-DAu1506 } & F: AGATGCGTGTATGCTGGAGT & $57^{\circ} \mathrm{C}$ \\
\hline & R: TGGGTACATGCCAATGCT & \\
\hline
\end{tabular}


Has-Ubiquitin were selected from a pool of potential reference genes [40,44] using the geNorm program [99]. Reference gene validity was also manually confirmed by visual examination of non-normalised, raw qPCR expression data. Normalisation of expression was done using the Relative Expression Software Tool for Rotor-Gene 3000 and 6000, Version 3 [100]. To authenticate differences in expression between gender/time point groups, twoway ANOVA and Tukey's HSD tests were performed using the $\mathrm{R}$ program [101], with P-values of 0.05 or lower taken as significant.

\section{Availability of supporting data}

The data sets supporting the results of this article are included within the article.

\begin{abstract}
Abbreviations
bp: base pair; CC: Cerebral commissure; $C D C H$ : Caudodorsal cell hormone; cDNA: complementary DNA; d: day/s; Da: Dalton; DBH: dorsal body hormone; EST: Expressed sequence tag; HGAP: Haliotid growth-associated peptide; h: hour; Has: Haliotis asinina; LG1/2: left cerebral ganglia section 1/2; MALDI-TOF-MS: matrix-assisted, laser desorption-ionisation time-of-flight mass spectrometry; min: minute; MIP: molluscan insulin-related peptide; $\mathrm{m} / \mathrm{z}$ : mass to charge ratio; PGM: pleuropedal ganglia middle section; qPCR: quantitative reverse transcription-polymerase chain reaction; RACE: rapid amplification of cDNA ends; RA/NRA: reproductively active anterior ganglia vs. non-reproductively active anterior ganglia; RG1/2: right cerebral ganglia section 1/2; s: second; SLP: schistosomin-like peptide; $\mathrm{SSH}$ : suppression substractive hybridisation.
\end{abstract}

\section{Competing interests}

The authors declare that they have no competing interests.

\section{Authors' contributions}

Project conception and sampling: S.Y., B.M.D., S.M.D. and S.C.; Gene characterisation: S.Y.; Proteomics: S.Y. and S.C.; Bioinformatics and phylogenetics: S.Y. and B.W.; Writing: S.Y., B.M.D., S.M.D. and S.C. All authors read and approved the final manuscript.

\section{Acknowledgements}

We thank Paul Palmer, Sizhong Wang, and the staff of the Bribie Island Research Centre within the Department of Employment, Economic Development and Innovation, for their support and use of the facility. We also thank Alina Tollenaere, Parinyaporn Nuurai, and Chitraporn Kuanpradit, for assistance in abalone collection and dissection, the staff of Heron Island Research Station for assistance with specimen collection requirements, and Piyachat Chansela - and the research group of Professor Prasert Sobhon - for helpful discussions about the APGWamide gene. This research was supported by a grant from the Australian Research Council to SMD and BMD.

\section{Author details}

${ }^{1}$ Centre for Marine Science, School of Biological Sciences, University of Queensland, Brisbane, Queensland 4072, Australia. ${ }^{2}$ Faculty of Science, Health, Education and Engineering, University of the Sunshine Coast, Maroochydore 4558, Australia. ${ }^{3}$ Australian Centre for Ecogenomics, University of Queensland, Brisbane, Queensland 4072, Australia.

Received: 15 March 2012 Accepted: 22 April 2012

Published: 9 May 2012

\section{References}

1. Bouchet P: The magnitude of marine biodiversity. In The Exploration of Marine Biodiversity: Scientific and Technological Challenges. Edited by Duarte CM. Bilbao: Fundación BBVA; 2006:31-62.

2. Chapman AD: Numbers of living species in Australia and the World. 2nd edition. Parkes, A.C.T. Department of the Environment, Water, Heritage and the Arts 2009.
3. Hoffman Jl, Peck LS, Linse K, Clarke A: Strong population genetic structure in a broadcast-spawning antarctic marine invertebrate. J Hered 2011, 102:55-66.

4. Imron, Jeffrey B, Hale P, Degnan BM, Degnan SM: Pleistocene isolation and recent gene flow in Haliotis asinina, an Indo-Pacific vetigastropod with limited dispersal capacity. Mol Ecol 2007, 16:289-304.

5. Kenchington EL, Patwary MU, Zouros E, Bird CJ: Genetic differentiation in relation to marine landscape in a broadcast-spawning bivalve mollusc (Placopecten magellanicus). Mol Ecol 2006, 15:1781-1796.

6. Capinpin EC, Encena VC, Bayona NC: Studies on the reproductive biology of the Donkey's ear abalone, Haliotis asinina Linne. Aquaculture 1998, 166:141-150.

7. Counihan RT, McNamara DC, Souter DC, Jebreen EJ, Preston NP, Johnson $C R$, Degnan BM: Pattern, synchrony and predictability of spawning of the tropical abalone Haliotis asinina from Heron Reef, Australia. Mar Ecol Prog Ser 2001, 213:193-202.

8. Fretter V: Prosobranchs. In The Mollusca: Reproduction. Volume 7. Edited by Wilbur KM. New York: Academic Press Inc; 1984:1-45.

9. Geraerts WPM, Joosse J: Freshwater snails (Basommatophora). In The Mollusca: Reproduction. Volume 7. Edited by Wilbur KM. New York: Academic Press, Inc; 1984:141-207.

10. Hadfield MG, Switzer-Dunlap M: Opisthobranchs. In The Mollusca: Reproduction. Volume 7. Edited by Wilbur KM. New York: Academic Press, Inc; 1984:209-350.

11. Babcock R: Synchronous multispecific spawning on coral reefs: Potential for hybridization and roles of gamete recognition. Reprod Fertil Dev 1995, 7:943-950.

12. Jebreen EJ, Counihan RT, Fielder DR, Degnan BM: Synchronous oogenesis during the semilunar spawning cycle of the tropical abalone Haliotis asinina. J Shellfish Res 2000, 19:845-851.

13. Babcock R, Mundy C, Keesing J, Oliver J: Predictable and unpredictable spawning events: in situ behavioural data from free-spawning coral reef invertebrates. Invertebr Reprod Dev 1992, 22:213-227.

14. Onitsuka T, Kawamura T, Horii T, Takiguchi N, Takami H, Watanabe Y: Synchronized spawning of abalone Haliotis diversicolor triggered by typhoon events in Sagami Bay, Japan. Mar Ecol Prog Ser 2007, 351:129-138.

15. Williams JR, Babcock RC: Comparison of multiple techniques to evaluate reproductive variability in a marine bivalve: application to the scallop Pecten novaezelandiae. Mar Freshw Res 2004, 55:457-468.

16. Toro JE, Thompson RJ, Innes DJ: Reproductive isolation and reproductive output in two sympatric mussel species (Mytilus edulis, M. trossulus) and their hybrids from Newfoundland. Mar Biol 2002, 141:897-909.

17. de Lange RPJ, Joosse J, van Minnen J: Multi-messenger innervation of the male sexual system of Lymnaea stagnalis. J. Comp Neurol 1998, 390:564-577.

18. van Golen FA, Li KW, Delange RPJ, Vankesteren RE, Vanderschors RC, Geraerts WPM: Co-localized neuropeptides conopressin and ALA-PROGLY-TRP-NH2 have antagonistic effects on the vas deferens of Lymnaea. Neuroscience 1995, 69:1275-1287.

19. Geraerts WPM, Smit AB, Li KW, Vreugdenhil E, van Heerikhuizen $\mathrm{H}$ Neuropeptide gene families that control reproductive behaviour and growth in molluscs. In Current Aspects of the Neurosciences. Volume 3. Edited by Osborne NN. London: MacMillan Press; 1991: 255-304.

20. Geraerts WPM, Smit AB, Li KW, Hordijk PL: The light green cells of Lymnaea: a neuroendocrine model system for stimulus-induced expression of multiple peptide genes in a single cell type. Experientia 1992, 48:464-473.

21. Greenberg MJ, Doble KE, Lesser W, Lee TD, Pennell NA, Morgan CG, Price DA: Characterization of myomodulin-related peptides from the pulmonate snail Helix aspersa. Peptides 1997, 18:1099-1106.

22. Henry J, Zatylny C, Boucaud-Camou E: Peptidergic control of egg-laying in the cephalopod Sepia officinalis: involvement of FMRFamide and FMRFamide-related peptides. Peptides 1999, 20:1061-1070.

23. Li KW, van Golen FA, van Minnen J, van Veelen PA, van der Greef J, Geraerts WPM: Structural identification, neuronal synthesis, and role in male copulation of myomodulin-A of Lymnaea: a study involving direct peptide profiling of nervous tissue by mass spectrometry. Brain Res $\mathrm{Mol}$ Brain Res 1994, 25:355-358.

24. Miller MW, Alevizos A, Cropper EC, Vilim FS, Karagogeos D, Kupfermann I, Weiss KR: Localization of myomodulin-like immunoreactivity in the 
central nervous system and peripheral tissues of Aplysia californica. J Comp Neurol 1991, 314:627-644.

25. van Golen FA, Li KW, Chen S, Jimenez CR, Geraerts WPM: Various isoforms of myomodulin identified from the male copulatory organ of Lymnaea show overlapping yet distinct modulatory effects on the penis muscle. J Neurochem 1996, 66:321-329.

26. Nassel DR: Peptidergic neurohormonal control systems in invertebrates. Curr Opin Neurobiol 1996, 6:842-850.

27. Chansela P, Saitongdee P, Stewart P, Soonklang N, Stewart M, Suphamungmee W, Poomtong T, Sobhon P: Existence of APGWamide in the testis and its induction of spermiation in Haliotis asinina Linnaeus. Aquaculture 2008, 279:142-149.

28. Dogterom GE, Bohlken S, Geraerts WPM: A rapid in vivo bioassay of the ovulation hormone of Lymnaea stagnalis. Gen Comp Endocrinol 1983 50:476-482

29. Geraerts WPM, Joosse J: Control of vitellogenesis and of growth of female accessory sex organs by the dorsal body hormone (DBH) in the hermaphroditic freshwater snail Lymnaea stagnalis. Gen Comp Endocrinol 1975, 27:450-464

30. Phares GA, Lloyd PE: Purification, primary structure, and neuronal localization of cerebral peptide 1 from Aplysia. Peptides 1996, 17:753-761.

31. Fan XM, Croll RP, Wu B, Fang L, Shen Q, Painter SD, Nagle GT: Molecular cloning of a CDNA encoding the neuropeptides APGWamide and cerebral peptide 1: localization of APGWamide-like immunoreactivity in the central nervous system and male reproductive organs of Aplysia. J Comp Neurol 1997, 387:53-62.

32. Cummins SF, York PS, Hanna PJ, Degnan BM, Croll RP: Expression of prohormone convertase 2 and the generation of neuropeptides in the developing nervous system of the gastropod Haliotis. Int J Dev Biol 2009 53:1081-1088

33. Nicholas KB, Nicholas HB Jr, Deerfield DW II: GeneDoc: analysis and visualization of genetic variation. EMBNEW News 1997, 4:14

34. Veenstra JA: Neurohormones and neuropeptides encoded by the genome of Lottia gigantea, with reference to other mollusks and insects. Gen Comp Endocrinol 2010, 167:86-103.

35. Smit A, Jimenez C, Dirks R, Croll R, Geraerts W: Characterization of a cDNA clone encoding multiple copies of the neuropeptide APGWamide in the mollusk Lymnaea stagnalis. J Neurosci 1992, 12:1709-1715.

36. York PS, Cummins SF, Degnan SM, Woodcroft BJ, Degnan BM: Identification of genes differentially expressed in the ganglia of growing Haliotis asinina. J Shellfish Res 2010, 29:741-752.

37. Jackson DJ, McDougall C, Woodcroft B, Moase P, Rose RA, Kube M Reinhardt R, Rokhsar DS, Montagnani C, Joubert C, Piquemal D, Degnan BM: Parallel evolution of nacre building gene sets in molluscs. Mol Biol Evol 2010, 27:591-608.

38. Miller M, Beushausen S, Vitek A, Stamm S, Kupfermann I, Brosius J, Weiss K: The myomodulin-related neuropeptides: characterization of a gene encoding a family of peptide cotransmitters in Aplysia. J Neurosci 1993, 13:3358-3367.

39. Kellett E, Perry SJ, Santama N, Worster BM, Benjamin PR, Burke JF: Myomodulin gene of Lymnaea: structure, expression, and analysis of neuropeptides. J Neurosci 1996, 16:4949-4957.

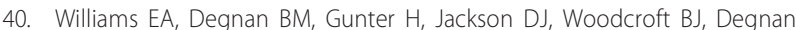
SM: Widespread transcriptional changes pre-empt the critical pelagic-benthic transition in the vetigastropod Haliotis asinina Mol Ecol 2009, 18:1006-1025.

41. Moroz LL, Edwards JR, Puthanveettil SV, Kohn AB, Hla T, Heyland A, Knudsen L, Sahni A, Yu FH, Liu L, Jezzini S, Lovell P, lannucculli W, Chen MC, Nguyen T, Sheng HT, Shaw R, Kalachikov S, Panchin YV, Farmerie W, Russo JJ, Ju JY, Kandel ER: Neuronal transcriptome of Aplysia: neuronal compartments and circuitry. Cell 2006, 127:1453-1467.

42. Koert CE, Spencer GE, van Minnen J, Li KW, Geraerts WPM, Syed NI, Smit $A B$, van Kesteren RE: Functional implications of neurotransmitte expression during axonal regeneration: serotonin, but not peptides, auto-regulate axon growth of an identified central neuron. J Neurosci 2001, 21:5597-5606.

43. von Bolen und Halbach O, Dermietzal R: Neurotransmitters and neuromodulators: handbook of receptors and biological effects. 2nd edition. Weinheim: Wiley-VCH; 2006

44. York PS, Cummins SF, Lucas T, Blomberg SP, Degnan SM, Degnan BM: Differential expression of neuropeptides correlates with growth rate in cultivated Haliotis asinina (Vetigastropoda: Mollusca). Aquaculture 2012, 334-337:159-168.

45. Cummins SF, Tollenaere A, Degnan BM, Croll RP: Molecular analysis of two FMRFamide-encoding transcripts expressed during the development of the tropical abalone Haliotis asinina. J Comp Neurol 2011, 519:2043-2059.

46. Korneev S, Fedorov A, Collins R, Blackshaw S, Davies J: A subtractive CDNA library from an identified regenerating neuron is enriched in sequences up-regulated during nerve regeneration. Invert Neurosci 1997, 3:185-192.

47. van Tol-Steye H, Lodder JC, Planta RJ, van Heerikhuizen H, Kits KS: Convergence of multiple G-protein-coupled receptors onto a single type of potassium channel. Brain Res 1997, 777:119-130.

48. van Tol-Steye H, Lodder JC, Mansvelder HD, Planta RJ, van Heerikhuizen H, Kits KS: Roles of G-protein beta gamma, arachidonic acid, and phosphorylation inconvergent activation of an S-like potassium conductance by dopamine, Ala-Pro-Gly-Trp-NH2, and Phe-Met-Arg-Phe-NH2. J Neurosci 1999, 19: 3739-3751.

49. Bernay B, Baudy-Floc'h M, Zanuttini B, Zatylny C, Pouvreau S, Henry J: Ovarian and sperm regulatory peptides regulate ovulation in the oyster Crassostrea gigas. Mol Reprod Dev 2006, 73:607-616.

50. Cropper EC, Tenenbaum R, Kolks MAG, Kupfermann I, Weiss KR: Myomodulin - a bioactive neuropeptide present in an identified cholinergic buccal motor-neuron of Aplysia. Proc Natl Acad Sci U S A 1987, 84:5483-5486.

51. Perry SJ, Straub VA, Kemenes G, Santama N, Worster BM, Burke JF, Benjamin PR: Neural modulation of gut motility by myomodulin peptides and acetylcholine in the snail Lymnaea. J Neurophysiol 1998, 79:2460-2474.

52. Proekt A, Vilim FS, Alexeeva V, Brezina V, Friedman A, Jing J, Li LJ, Zhurov Y, Sweedler JV, Weiss KR: Identification of a new neuropeptide precursor reveals a novel source of extrinsic modulation in the feeding system of Aplysia. J Neurosci 2005, 25:9637-9648.

53. Brezina V, Bank B, Cropper EC, Rosen S, Vilim FS, Kupfermann I, Weiss KR: Nine members of the myomodulin family of peptide cotransmitters at the B16-ARC neuromuscular junction of Aplysia. J Neurophysiol 1995, 74:54-72.

54. Brezina V, Evans CG, Weiss KR: Activation of $K$ current in the accessory radula closer muscle of Aplysia californica by neuromodulators that depress its contractions. J Neurosci 1994, 14:4412-4432.

55. Brezina V, Evans CG, Weiss KR: Enhancement of Ca current in the accessory radula closer muscle of Aplysia californica by neuromodulators that potentiate its contractions. J Neurosci 1994, 14:4393-4411.

56. Blackshaw SE, Babington EJ, Emes RD, Malek J, Wang WZ: Identifying genes for neuron survival and axon outgrowth in Hirudo medicinalis. J Anat 2004, 204:13-24.

57. Bechtold DA, Luckman SM: The role of RFamide peptides in feeding. J Endocrinol 2007, 192:3-15.

58. Di Cristo C, Delli Bovi P, Di Cosmo A: Role of FMRFamide in the reproduction of Octopus vulgaris: molecular analysis and effect on visual input. Peptides 2003, 24:1525-1532.

59. Roszer T, Banfalvi G: FMRFamide-related peptides: anti-opiate transmitters acting in apoptosis. Peptides 2011.

60. Khan HR, Price DA, Doble KE, Greenberg MJ, Saleuddin ASM: FMRFamide-related peptides, partial serotonin depletion, and osmoregulation in Helisoma duryi (mollusca: pulmonata). J Comp Neurol 1998, 393:25-33.

61. Khan HR, Price DA, Doble KE, Greenberg MJ, Saleuddin A: Osmoregulation and FMRFamide-related peptides in the salt marsh snail Melampus bidentatus (Say) (Mollusca: Pulmonata). Biol Bull 1999, 196:153-162.

62. Madrid KP, Price DA, Greenberg MJ, Khan HR, Saleuddin ASM: FMRFamide-related peptides from the kidney of the snail, Helisoma trivolvis. Peptides 1994, 15:31-36.

63. Salzet M, Bulet $P$, Wattez C, Malecha J: FMRFamide-related peptides in the sex segmental ganglia of the Pharyngobdellid leech Erpobdella octoculata. Eur J Biochem 1994, 221:269-275.

64. Kreshchenko N, Sheiman I, Reuter M, Gustafsson MKS, HHalton DW, Maule AG: Effects of FMRFamide-related peptides and Neuropeptide F on planarian regeneration (Platyhelminthes, Tricladida). Belg J Zool 2001, 131(1):147-148.

65. Kreshchenko ND: Functions of flatworm neuropeptides NPF, GYIRF and FMRF in course of pharyngeal regeneration of anterior body fragments of planarian, Girardia tigrina. Acta Biol Hung 2008, 59(Suppl):199-207.

66. Moffett SB: Neural regeneration in gastropod molluscs. Prog Neurobiol 1995, 46:289-330. 
67. Brussaard AB, Kits KS, Ter Maat A, Van Minnen J, Moed PJ: Dual inhibitory action of FMRFamide on neurosecretory cells controlling egg laying behavior in the pond snail. Brain Res 1988, 447:35-51.

68. Di Cristo C, Paolucci M, Iglesias J, Sanchez J, Di Cosmo A: Presence of two neuropeptides in the fusiform ganglion and reproductive ducts of Octopus vulgaris: FMRFamide and gonadotropin-releasing hormone (GnRH). J Exp Zool 2002, 292:267-276.

69. Fisher $T$, Lin $\mathrm{CH}$, Kaczmarek LK: The peptide FMRFa terminates a discharge in Aplysia bag cell neurons by modulating calcium, potassium, and chloride conductances. J Neurophysiol 1993, 69:2164-2173.

70. Marciniak P, RosiŃSki G: Comparison of proctolin and FMRFamide actions on the motility of male and female beetle reproductive tracts. Invertebr Reprod Dev 2010, 54:1-6.

71. Santama N, Benjamin PR: Gene expression and function of FMRFamide-related neuropeptides in the snail Lymnaea. Microsc Res Tech 2000, 49:547-556.

72. van Golen FA, Li KW, de Lange RP, Jespersen S, Geraerts WP: Mutually exclusive neuronal expression of peptides encoded by the FMRFa gene underlies a differential control of copulation in Lymnaea. J Biol Chem 1995, 270:28487-28493.

73. Fairweather I, Skuce PJ: Flatworm neuropeptides — present status, future directions. Hydrobiologia 1995, 305:309-316.

74. de Jong-Brink M, Elsaadany MM, Boer HH: Schistosomin, an antagonist of calfluxin. Exp Parasitol 1988, 65:109-118.

75. Hordijk PL, Ebberink RHM, Dejongbrink M, Joosse J: Isolation of schistosomin, a neuropeptide which antagonizes gonadotropic hormones in a freshwater snail. Eur J Biochem 1991, 195:131-136.

76. Hordijk PL, Schallig H, Ebberink RHM, Dejongbrink M, Joosse J: Primary structure and origin of schistosomin, an anti-gonadotropic neuropeptide of the pond snail Lymnaea stagnalis. Biochem J 1991, 279:837-842.

77. Hordijk PL, Vanloenhout H, Ebberink RHM, Dejongbrink M, Joosse J: Neuropeptide schistosomin inhibits hormonally-induced ovulation in the freshwater snail Lymnaea stagnalis. J Exp Zool 1991, 259:268-271.

78. De Jong-Brink M, Elsaadany M, Soto MS: The occurrence of schistosomin, an antagonist of female gonadotropic hormones, is a general phenomenon in haemolymph of schistosome-infected freshwater snails. Parasitology 1991, 103:371-378.

79. Hordijk PL, De Jong-Brink M, Termaat A, Pieneman AW, Lodder JC, Kits KS: The neuropeptide schistosomin and haemolymph from parasitized snails induce similar changes in excitability in neuroendocrine cells controlling reproduction and growth in a freshwater snail. Neurosci Lett 1992 136:193-197.

80. Zhang SM, Nian H, Wang B, Loker ES, Adema CM: Schistosomin from the snail Biomphalaria glabrata: expression studies suggest no involvement in trematode-mediated castration. Mol Biochem Parasitol 2009, 165:79-86.

81. Heyland A, Vue Z, Voolstra CR, Medina M, Moroz LL: Developmental transcriptome of Aplysia californica. J Exp Zool B Mol Dev Evol 2011, 316B:113-134.

82. Floyd PD, Li LJ, Rubakhin SS, Sweedler JV, Horn CC, Kupfermann I, Alexeeva VY, Ellis TA, Dembrow NC, Weiss KR, Vilim FS: Insulin prohormone processing, distribution, and relation to metabolism in Aplysia californica. J Neurosci 1999, 19:7732-7741.

83. Geraerts WPM: Control of growth by the neurosecretory hormone of the light green cells in the freshwater snail Lymnaea stagnalis. Gen Comp Endocrinol 1976, 29:61-71.

84. Geraerts WPM: The role of the lateral lobes in the control of growth and reproduction in the hermaphrodite freshwater snail Lymnaea stagnalis. Gen Comp Endocrinol 1976, 29:97-108.

85. Widjenes J, Runham NW: Studies on the control of growth in Agriolimax reticulatus (mollusca, pulmonata). Gen Comp Endocrinol 1977, 31:154-156.

86. Kits KS, Bobeldijk RC, Crest M, Lodder JC: Glucose-induced excitation in molluscan central neurons producing insulin-related peptides. Pflugers Arch 1991, 417:597-604.

87. Adam and Amos Abalone Foods Pty Ltd. [http://www.adamamos.com/].

88. National Center for Biotechnology Information. [http://www.ncbi.nlm.nih.gov/].

89. Camacho C, Coulouris G, Avagyan V, Ma N, Papadopoulos J, Bealer K, Madden TL: BLAST plus: architecture and applications. BMC Bioinformatics 2009, 10:421.

90. NeuroPred. [http://neuroproteomics.scs.illinois.edu/cgi-bin/neuropred.py].

91. Southey BR, Amare A, Zimmerman TA, Rodriguez-Zas SL, Sweedler JV: NeuroPred: a tool to predict cleavage sites in neuropeptide precursors and provide the masses of the resulting peptides. Nucleic Acids Res 2006 34:W267-W272.

92. SignalP. [http://www.cbs.dtu.dk/services/SignalP/].

93. Dyrløv Bendtsen J, Nielsen H, von Heijne G, Brunak S: Improved prediction of signal peptides. SignalP 3.0. J Mol Biol 2004, 340:783-795.

94. SIG-Pred. [http://bmbpcu36.leeds.ac.uk/prot_analysis/Signal.html].

95. Tamura K, Dudley J, Nei M, Kumar S: MEGA4: Molecular evolutionary genetics analysis (MEGA) software version 4.0. Mol Biol Evol 2007, 24:1596-1599.

96. Larkin MA, Blackshields G, Brown NP, Chenna R, McGettigan PA, McWilliam $H$, Valentin F, Wallace IM, Wilm A, Lopez R, Thompson JD, Gibson TJ, Higgins DG: Clustal W and Clustal X version 2.0. Bioinformatics 2007, 23:2947-2948

97. Rozen S, Skaletsky HJ: Primer3 on the WWW for general users and for biologist programmers. In Bioinformatics Methods and Protocols: Methods in Molecular Biology. Volume 132. Edited by Krawetz S, Misener S. Totowa: Humana Press; 2000:365-386.

98. Primer3. [http://frodo.wi.mit.edu/primer3/].

99. Vandesompele J, De Preter K, Pattyn F, Poppe B, Van Roy N, De Paepe A, Speleman F: Accurate normalization of real-time quantitative RT-PCR data by geometric averaging of multiple internal control genes. Genome Biol 2002, 3:12

100. Pfaffl MW, Horgan GW, Dempfle L: Relative expression software tool (REST (c)) for group-wise comparison and statistical analysis of relative expression results in real-time PCR. Nucleic Acids Res 2002, 30(9):e36.

101. R Development Core Team: $R$ : a language and environment for statistical computing. Vienna, Austria: R Foundation for Statistical Computing; 2010.

doi:10.1186/1742-9994-9-9

Cite this article as: York et al:: Marked changes in neuropeptide expression accompany broadcast spawnings in the gastropod Haliotis asinina. Frontiers in Zoology 2012 9:9.

\section{Submit your next manuscript to BioMed Central and take full advantage of:}

- Convenient online submission

- Thorough peer review

- No space constraints or color figure charges

- Immediate publication on acceptance

- Inclusion in PubMed, CAS, Scopus and Google Scholar

- Research which is freely available for redistribution

Submit your manuscript at www.biomedcentral.com/submit
C Biomed Central 